\title{
TRANSPORTASI PARA PEJUANG PADA MASA REVOLUSI FISIK DI BALI 1945-1950
}

\author{
Ida Bagus Astika Pidada \\ Universitas Warmadewa \\ astikapidada@gmail.com
}

\begin{abstract}
ABSTRAK
Atas nama bangsa Indonesia IR. Sukarno yang di dampingi Drs. Mohammad Hatta pada tanggal 17 Agustus 1945 memproklamirkan kemerdekaan Indonesia di Jalan Pegangsaan Timur No 56 Jakarta pada jam 10.00 WIB. Berita proklamasi kemerdekaan Indonesia baru di dengar di Bali tanggal 23 Agustus 1945 sejak kembalinya MR. I Gusti Ketut Puja dari Jakarta. Berita proklamasi terlambat sampai di Bali karena kurang lancarnya komunikasi dan transportasi dengan pulau Jawa. Pada waktu ini Jepang masih menunjukkan sikap berkuasa di Bali, oleh sebab itu pada tanggal 13 Desember 1945 diadakan serangan umum terhadap tangsi - tangsi Jepang di Seluruh Bali. Serangan ini ternyata menemui kegagalan karena Jepang telah mengetahui terlebih dahulu. Sehubungan tidak mungkin mendapatkan senjata di Bali, I Gusti Ngurah Rai dan kawan - kawan akhirnya berangkat pergi ke Jawa untuk melaporkan situasi di Bali serta meminta bantuan senjata. Setelah beberapa lama tinggal di pulau Jawa pada tanggal 4 April 1946 I Gusti Ngurah Rai dan kawan - kawan akhirnya kembali ke Bali dimana mendarat di Yeh Kuning. Dari sini I Gusti Ngurah Rai melanjutkan perjalanan menuju desa Munduk Malang. Dari desa Munduk Malang I Gusti Ngurah Rai mengadakan serangan terhadap tangsi - tangsi Belanda/NICA di sekitarnya. Berhubung kedudukan markas I Gusti Ngurah Rai dan pasukannya di ketahui oleh Belanda/NICA maka diputuskan untuk mengadakan "Long March" atau dikenal pula dengan sebutan "Perjalanan Juni - Juli". Adapun tujuan mengadakan long march adalah untuk menambah semangat rakyat, mengalihkan perhatian Belanda ke daerah timur, serta memudahkan bantuan dari Jawa ke Bali. Selain para pejuang menggunakan jalan kaki pada masa revolusi fisik di Bali untuk dapat berhubungan dengan para pejuang yang lain juga digunakan transportasi. Transportasi digunakan oleh para pejuang untuk perjalanan jauh dan apabila situasi aman. Transportasi yang digunakan pada waktu ini selain berjalan kaki juga menggunakan seperti: kendaraan truk, sedan, pick up, bus, sepeda, dokar, pedati, serta perahu untuk di laut. Dengan sarana ini komunikasi antar para pejuang tetap nyambung sehingga perjuangan di Bali cukup lama dapat bertahan dalam menghadapi Belanda/NICA.
\end{abstract}

Kata kunci: NICA; para pejuang; transportasi

\begin{abstract}
On behalf of the Indonesian nation IR. Sukarno who was accompanied by Drs. Mohammad Hatta on August 17th, 1945 proclaimed Indonesian independence on Jalan Pegangsaan Timur No. 56 Jakarta at 10:00 am. News of the proclamation of Indonesian independence was only heard in Bali on August 23rd 1945 since the return of Mr. I Gusti Ketut Puja from Jakarta. News of the proclamation arrived late in Bali due to lack of communication and transportation with the island of Java. At this time Japan was still showing an attitude of power in Bali, therefore on December 13th 1945 a general attack was carried out against Japanese protests throughout Bali. This attack turned out to be a failure because Japan had known in advance. Since it was impossible to get weapons in Bali, I Gusti Ngurah Rai and his friends finally went to Java to report on the situation in Bali and asked for weapons. After some time living on the island of Java on April 4th, 1946 I Gusti Ngurah Rai and his friends finally returned to Bali where it landed at Yeh Kuning. From here I Gusti Ngurah Rai continued his journey to the village of Munduk Malang. From the village of Munduk Malang, I Gusti Ngurah Rai carried out an attack on the Dutch / NICA ambushes around him. Due to the position of I Gusti Ngurah Rai headquarters and its troops being known by the Netherlands / NICA, it was decided to hold a "Long March" or also known as "The June-July Trip".
\end{abstract}


Long March starts by walking from Bengkel Anyar Village by climbing Mount Batukaru to Mount Agung. The purpose of holding a long march is to increase the people's enthusiasm, divert Dutch attention to the east, and facilitate assistance from Java to Bali. In addition to the fighters using walking during the physical revolution in Bali to be able to connect with other fighters also used transportation. Transportation is used by fighters for long trips and when the situation is safe. Transportation that is used at this time besides walking also uses such as truck, sedan, pickup, bus, bicycle, dock, cart, and boat for the sea. With this means of communication between the fighters remain connected so that the struggle in Bali can last long enough to face the Netherlands / NICA.

Keywords: NICA; fighters; transportation

\section{PENDAHULUAN}

Atas nama Bangsa Indonesia IR. Sukarno yang di damping Drs. Mohammad Hatta pada tanggal 17 Agustus 1945 memproklamirkan kemerdekaan Indonesia di Jalan Pegangsaan Timur No 56 Jakarta pada jam 10.00 WIB (Kartodirdjo \& (dkk.), 1977: 29). Berita proklamasi kemerdekaan Indonesia baru di dengar di Bali tanggal 23 Agustus 1945 setelah Mr. I Gusti Ketut Puja kembali dari Jakarta (Hardjawiganda \& (dkk.), 1982: 7). Berita kemerdekaan Indonesia terlambat sampai di pulau Bali disebabkan karena kurang lancarnya transportasi dan komunikasi dengan pulau Jawa. Di Bali Jepang pada waktu ini masih mempertahankan kekuasaannya, padahal Jepang sudah menyerah kepada Sekutu. Melihat sikap Jepang yang demikian untuk mendapatkan senjata, maka diadakan serangan umum tanggal 13 Desember 1945 kepada seluruh tangsi - tangsi Jepang di Bali. Serangan ini dilakukan pada malam hari pukul 13.00 dengan melibatkan seluruh rakyat yang bersenjatakan bambu runcing, tombak, keris, golok serta senjata lainnya. Namun demikian Jepang sudah mengetahui terlebih dahulu sehingga melepaskan tembakan salvo yang amat hebat. Meskipun begitu sesuai dengan rencana yang ditetapkan kentongan tetap dibunyikan. Ini berarti serangan umum 13 Desember 1945 menemui kegagalan (Pindha, 1972: 19-28). Sehubungan di Bali tidak mungkin mendapatkan senjata, pada tanggal 19 Desember 1945 I Gusti Ngurah Rai, Wayan Ledang, Putu Wisnu, dan Cokorda Ngurah berangkat bersama - sama ke Jawa melalui Munsiang. Maksud dari keberangkatan ini untuk meminta bantuan senjata serta melaporkan keadaan di Bali. Selama perjalanan ini semua dapat di atasi dan mendarat dengan selamat di daerah Wongsorejo yakni kurang lebih $20 \mathrm{~km}$ di sebelah utara Banyuwangi (Hardjawiganda \& (dkk.), 1982: 44).

Selanjutnya pada tanggal 2 Maret 1946 di pantai Sanur mendaratlah rombongan Belanda bernama brigade $\mathrm{Y}$. Rombongan brigade $\mathrm{Y}$ yang dikenal dengan nama "Gajah Merah" mendarat di pulau Bali dan pulau Lombok. Gajah Merah di Bali dipimpin oleh komandan Letkol Ter Meulen dan Letkol Piter Camp yakni batalyon 10 dan 11. Setelah Gajah Merah mendarat di Bali langsung menduduki: 1). Denpasar yakni tanggal 2 Maret 1946, 2). selanjutnya Gianyar tanggal 3 Maret 1946, 3). menyusul Singaraja tanggal 5 Maret 1946, 4). berikutnya Tabanan, Bangli, Klungkung, dan Karangasem tanggal 7 Maret 1946, dan terakhir 5). Negara yaitu tanggal 13 Maret 1946. Pulau Bali selanjutnya dibagi oleh Belanda menjadi 3 komando militer antara lain: Denpasar, Gianyar dipegang oleh Kapten Cassa. Daerah Bangli, Klungkung, dan Karangasem dipegang oleh Letnan Groet. Kemudian Kapten Ter Wilde memegangt daerah Tabanan, Negara, dan Singaraja (Hardjawiganda \& (dkk.), 1982: 4849). Dengan mendaratnya pasukan Gajah Merah di Bali menyebabkan situasi menjadi genting serta tidak tenang. Melihat situasi demikian Belanda menarik kembali pasukannya di Lombok lagi 3 kompi.

Setelah kurang lebih 3 bulan berada di Jawa, I Gusti Ngurah Rai dan kawan - kawan kembali ke Bali. Melalui bantuan pasukan ALRI Banyuwangi I Gusti Ngurah Rai dan kawan - kawan pada tanggal 3 April 1946 sekitar pukul 20.00 malam berangkat dari Muncar menuju Bali. Dalam perjalanan menuju ke Bali pada pukul 03.00 pagi, dari arah timur mucul 2 buah motor bot Belanda. Belanda tanpa komentar karena telah mengetahui bahwa perahu yang lewat adalah pejuang segera melepaskan tembakan otomatisnya. Akibat 
tembakan senjata Belanda ini gugur 2 orang pejuang yaitu Cokorda Gambir dan Cokorda Dharmna Putra sedangkan tukang perahunya ditangkap. Ketika peristiwa ini terjadi posisi I Gusti Ngurah Rai berada di belakang perahu Cokorda Gambir dan Cokorda Dharma Putra sekitar 1 kilometer. I Gusti Ngurah Rai mendengar suara termbakan tersebut segera mengambil keputusan untuk kembali lagi ke daerah Muncar. I Gusti Ngurah Rai dan kawan - kawan kembali melanjutkan perjalanan ke Bali pada tanggal 4 April 1946 pukul 24.00 malam dan mendarat di Yeh Kuning sebanyak 3 perahu sedangkan sisanya di Pulukan. Salah satu diantaranya yang mendarat di Pulukan yaitu Cokorda Ngurah (Pendit, 1979: 157). Berhubung situasi kurang aman di daerah ini, I Gusti Ngurah Rai memutuskan untuk melanjutkan perjalanan kembali ke Desa Munduk Malang di daerah Tabanan sesuai apa direncanakan sebelumnya. Sebelum I Gusti Ngurah Rai mendarat beberapa truk Belanda telah datang ke Yeh Kuning, karena para pejuang yang ditunggu tidak datang pasukan Belanda selanjutnya pindah ke arah barat.

Setelah I Gusti Ngurah Rai sampai di Desa Munduk Malang selanjutnya pada tanggal 14 April 1946 berkumpullah tokoh - tokoh para pejuang di desa ini. Di desa ini dibahas situasi perjuangan di daerah Bali serta menceriterakan keadaan di Jawa khususnya di daerah Yogyakarta. Di Desa Munduk Malang para pejuang membentuk Markas Besar Umum Dewan Perjuangan Rakyat Indonesia Sunda Kecil (MBUDPRISK) dengan pimpinan Letnan Kolonel I Gusti Ngurah Rai sedangkan wakilnya dipilih Made Wijakusuma (Jajasan Kebaktian Proklamasi Daerah Propinsi Bali, 1968: 4). Selanjutnya dari desa ini diadakan serangan kepada pos - pos Belanda seperti: di Desa Penebel Utara (Tabanan Utara) dan pencegatan konvoi Belanda di Desa Pucuk (Kecamatan Selemadeg). Adanya serangan serangan ini dalam waktu singkat Belanda mengetahui posisi para pejuang di Desa Munduk Malang juga dibantu oleh para kaki tangannya. Melihat kondisi Desa Munduk Malang tidak aman selanjutnya Markas Besar Umum (MBO) dipindahkan ke sebelah timur laut yakni ke Desa Bengkel Anyar. Desa Bengkel Anyar terletak kurang lebih $7 \mathrm{~km}$ dari Desa Munduk Malang (Pendit, 1979: 180).
Berhubung situasi semakin sulit serta datangnya utusan para pejuang dari masing masing daerah, untuk menambah semangat rakyat di bawah pimpinan I Gusti Ngurah Rai diputuskan mengadakan perjalanan panjang dari Bali Barat ke Bali Timur yang dikenal dengan nama "Perjalanan Juni - Juli " atau "Long March" (Pendit, 1979: 189). Long March di mulai tanggal 28 Mei 1946 dari Desa Bengkel Anyar menuju daerah Buleleng dengan mendaki daerah Gunung Batukaru sampai Gunung Agung dengan berjalan kaki. Namun demikian para pejuang yang lain masih dapat menggunakan transportasi pada masa revolusi fisik untuk dapat berkomunikasi antar para pejuang.

\section{PEMBAHASAN}

Transportasi menurut Kamus Besar Bahasa Indonesia diartikan: perihal (seluk - beluk) transpor. Transpor diartikan angkutan baik berupa alat, barang - barang. Transportasi adalah perpindahan manusia atau barang dari satu tempat ke tempat lainnya dengan menggunakan sebuah kendaraan (angkutan) baik yang digerakkan oleh manusia, tenaga mesin maupun hewan (Balai Pustaka, 2001: 1210).

Sedangkan pengertian pejuang menurut Poerwadarminta orang yang berjuang, prajurit (Poerwadarminta, 1976: 424 - 723).

Begitu halnya dengan pengertian revolusi dapat dikemukakan beberapa pendapat antara lain : A.H. Nasution revolusi adalah meruntuhkan sistem - sistem lama (Nasution,A, 1977: 234). Menurut Sartono Kartodirdjo revolusi adalah proses politik yang timbul pada situasi kritis dimana golongan yang konflik mengusahakan perubahan politik secara radikal (Kartodirdjo, 1970: 12). Sedangkan I Nyoman Dekker mengatakan revolusi adalah perubahan dengan cara cepat yang sifatnya fundamental terjadi dalam waktu singkat (Dekker, 1980: 13-14).

Jadi yang dimaksud dengan revolusi adalah perubahan dengan cara cepat sifatnya fundamental terjadi pada situasi kritis dimana golongan - golongan yang konflik bertujuan meruntuhkan sistem - sistem lama dengan cara radikal.

Demikian halnya dengan revolusi fisik yang terjadi di Bali para pejuang melakukan 
perlawanan kepada Belanda (NICA) karena tidak ingin dijajah kembali. Pada waktu ini pejuang dalam menghadapi Belanda (NICA) menggunakan berbagai macam transportasi untuk dapat berhubungan antar para pejuang baik dengan berjalan kaki atau menggunakan sarana angkutan lainnya, sehingga komunikasi tetap berjalan lancar antar para pejuang. Dengan demikian para pejuang di Bali dalam melawan Belanda (NICA) cukup lama dapat bertahan lama.

Mengenai periode waktu yang digunakan pada tulisan ini meliputi tahun $1945-1950$. Tahun 1945 dipakai batasan awal karena setelah proklamasi kemerdekaan Indonesia perjuangan bangkit kembali untuk menentang penjajah (Belanda/NICA) karena ingin menguasai kembali Indonesia pada umumnya dan Bali pada khususnya. Sedangkan tahun 1950 dipakai sebagai batasan akhir dari tulisan ini karena perjuangan di Bali sudah berakhir berhubung adanya penurunan gerilya karena pengakuan kedaulatan.

Pada masa revolusi fisik di Bali dari tahun 1945 - 1950 para pejuang menggunakan berbagai macam transportasi untuk dapat berhubungan antar para pejuang antara lain:

-Truk. Transportasi jenis ini pernah digunakan oleh para pejuang di daerah Badung dan Buleleng. Kendaraan truk sebanyak 5 buah pernah digunakan oleh pasukan TRI dari daerah Badung pergi ke daerah Buleleng untuk memberi bantuan pasukan Buleleng karena Sang Merah Putih dirampas oleh awak kapal Abraham Grijns. Peristiwa ini terjadi tanggal 27 Oktober 1945 (Pendit, 1979: 89).

-Pedati/Gedebeg (kereta yang ditarik menggunakan kerbau). Daerah Buleleng dan Negara pernah menggunakan transportasi ini. Pasukan Markadi pernah menggunakan kendaraan ini ketika datang ke daerah Negara yakni di Desa Peh. Markadi datang ke Desa Peh dalam rangka pembentukan markas di daerah itu. Peristiwa ini terjadi tanggal 10 April 1946 (Hardjawiganda \& (dkk.), 1982: 126).

-Sedan. Transportasi sedan pernah digunakan oleh para pejuang di daerah Bangli, Badung, dan Buleleng. Di daerah Bangli pejuang yang pernah menggunakan kendaraan sedan adalah Ida Bagus Kaler bersama - sama dengan Sang Made Kaler. Pada waktu ini Ida Bagus Kaler bersama - sama Sang Made Kaler menumpang kendaraan sedan milik Belanda dari Kintamani menuju Geria Bukit Bangli. Ida Bagus Kaler datang ke daerah Kintamani diterima oleh pejuang bernama I Made Ringin. Tujuan datang ke daerah Kintamani adalah untuk menyampaikan kepada para pejuang di daerah ini agar terus melanjutkan perjuangan. Peristiwa ini terjadi tahun 1946 (Hasil wawancara dengan Bapak Ida Bagus Kaler, 1985).

-Dokar (kereta yang ditarik dengan kuda). Transportasi jenis ini pernah digunakan oleh pejuang di daerah Badung, Tabanan, Negara, Buleleng, Karangasem, dan Klungkung. Pejuang wanita yang pernah menggunakan transportasi ini di daerah Tabanan yaitu Asimah. Asimah berangkat dari daerah Tabanan menuju ke rumah Ni Made Sundri di Banjar Titih (Badung) dalam rangka mencari peluru. Peristiwa ini terjadi pada tahun 1946 (Hasil wawancara dengan Ibu Asimah, 1985). Demikian halnya dengan Wijakusuma pernah juga menggunakan transportasi dokar ketika berada di daerah Klungkung. Dengan menggunakan pakaian adat pada jam 7 malam Wijakusuma berangkat dari rumah Pak Tugug di Desa Takmung menuju ke Puri Klungkung. Sebelum berangkat menuju ke puri Klungkung, Wijakusuma di make up terlebih dahulu yakni memakai pakaian adat lengkap menghadap raja. Agar dapat memasuki Puri Klungkung, Wijakusuma terlebih dahulu harus melewati penjaga puri yang bernama BKN (Badan Keamanan Negara). Selanjutnya Wijakusuma diantar langsung masuk ke belakang puri menuju ke sebuah rumah untuk tidur. Maksud kehadiran Wijakusuma sehari di puri Klungkung untuk memperoleh pengakuan serta disyahkan secara resmi perjuangan (Wijakusuma, 1979: IV).

-Sepeda. Jenis transportasi ini pernah digunakan oleh pejuang dari daerah Tabanan, Bangli, Klungkung, Karangasem, Gianyar, dan Buleleng. Di daerah Gianyar yang pernah menggunakan transportasi ini I Made Sanggra bersama - sama dengan I Nyoman Muna dari Banjar Gunung Desa Penatih ke kota Denpasar. Sepeda yang digunakan pada waktu itu merk Mister A buatan Jepang. Peristiwa ini terjadi pada tahun 1946 (Hasil wawancara dengan Bapak I Made Sanggra, 1985). Transportasi sepeda pernah juga digunakan oleh 
Wijakusuma setelah menghadap raja di puri Klungkung menuju daerah Karangasem. Di daerah Karangasem Wijakusuma di jemput oleh Widana di pinggir jalan di sebuah perkebunan kelapa. Widana pada waktu itu diperkirakan usianya sekitar 15 tahun dimana keadaan tubuhnya sama dengan Wijakusuma. Dari sini Wijakusuma menuju rumah Widana di tengah - tengah perkebunan kelapa yang diterima oleh ibu dari orang tua Widana. Setelah berganti pakaian adat yang digunakan dari Klungkung, pada malam harinya Widana bersama - sama Wijakusuma mengendarai sepeda di jalan raya menuju rumah Bapak Reni Pager, seorang pejuang yang gigih di daerah ini. Melalui Bapak Reni Pager Wijakusuma memperoleh informasi bahwa buruh - buruh yang bekerja di pelabuhan Padangbai dan Labuhan Amuk semua adalah pejuang pejuang yang dapat diandalkan (Wijakusuma, 1979: IV). Sepeda juga pernah digunakan di daerah Buleleng. Hal ini pernah dilakukan oleh Ketut Parwa dari Singaraja ke Bedolan (Munduk). Ketut Parwa ditugaskan membawa surat dengan memasukkan dalam ban sepeda. Ketut Parwa melaksanakan tugas ini atas perintah I Gusti Bagus Meraku Tirtayasa (Hasil wawancara dengan Bapak I Gusti Bagus Meraku Tirtayasa, 1985).

-Pick Up. Transportasi jenis ini pernah digunakan oleh pejuang dari daerah Tabanan. Pejuang yang pernah menggunakan transportasi pick up yaitu Ida Bagus Tantra. Ida Bagus Tantra menggunakan kendaraan pick up pada waktu pergi dari Desa Antagana menuju Desa Sembung. Peristiwa ini terjadi pada tahun 1949 (Hasil wawancara dengan Bapak Ida Bagus Tantra, 1984).

-Bus. Transportasi jenis ini pernah digunakan oleh pejuang di daerah Buleleng, Karangasem, dan Negara. Pejuang I Nyoman Nirba, I Nyoman Suka, Ketut Weda, dan Ketut Punia pernah menggunakan kendaraan bus dari daerah Negara menuju Desa Banjar (Buleleng) dalam rangka menemui pejuang Ida Bagus Tantra , I Nengah Tjilik, Cokorda Anom Sandat, dan Ida Bagus Tenaya. Adapun maksud kedatangannya ke Desa Banjar dalam rangka meminta instruksi, melaporkan situasi di daerah Negara, serta menyatakan tentang penurunan gerilya. Sopir bus transportasi yang ditumpangi tersebut bernama I Regig berasal dari banjar
Celagi Gendong Denpasar. Peristiwanya terjadi pada tahun 1949 (Hasil wawncara dengan Bapak I Nyoman Nirba, 1985).

-Jalan Kaki. Hal ini pernah dilakukan ketika pasukan I Gusti Ngurah Rai mengadakan "Long March" ke Gunug Agung atau dikenal juga perjalanan "Juni - Juli". Long March dilakukan dengan jalan kaki yakni mulai dengan mendaki Gunung Batukaru yang dilanjutkan dengan mendaki beberapa gunung yang lain sampai ke Gunung Agung. Pasukan penyelidik militer chusus (PMC) berada pada posisi paling depan dengan membawa senjata pistol dan senjata tajam pendek untuk merambas jalan yang terhalang. Dibelakang pasukan penyelidik militer chusus kurang lebih 100 (seratus) meter diikuti oleh dapur umum dan setelah itu dibelakangnya adalah pasukan sekaligus dengan pemimpinnya I Gusti Ngurah Rai (Hasil wawancara dengan Bapak I Made Sanggra, 1985). Demikian halnya ketika pasukan I Gusti Ngurah Rai kembali dari Tanah Aron (Gunung Agung) Karangasem, karena MBO di kurung oleh tentara Belanda serta tidak menemukan jalan terpaksa merambas membuat jalan baru. Adapun yang merambas jalan tersebut adalah Cokorda Ngurah (Punggawa Bangli) dimana sekaligus berfungsi sebagai penunjuk jalan (Pindha, 1964: 15). Akhirnya MBO sampai pada sebuah hutan cemara, dimana dalam keadaan kondisi lapar, haus dan payah akhirnya pasukan tersebut berhenti untuk beristirahat. Para peminpin perjuangan di Desa Nongan mendengar hal ini selanjutnya mengerahkan rakyatnya membuat ketupat untuk dikirim ke hutan cemara tempat pasukan I Gusti Ngurah Rai beristirahat. Mengangkut ketupat dari Desa Nongan menuju hutan cemara jaraknya sekitar $20 \mathrm{~km}$ dengan berjalan kaki melalui bukit serta melewati beberapa jurang. Kira - kira pada jam 22.00 malam ketupat yang diharapkan oleh pasukan I Gusti Ngurah Rai akhirnya datang juga. Dari 14 pikul ketupat yang dikirim hanya 2 pikul saja yang sampai di tempat tujuan, karena telah dihadang terlebih dahulu oleh tentara NICA di sebelah timur desa Pempatan. Para tukang pikul ketupat ini sebanyak 12 orang selanjutnya ditangkap oleh tentara NICA sedangkan sisanya lagi 2 orang berhasil lolos dengan bersembunyi terlebih dahulu (Pindha, 1968). Jalan kaki pernah juga dilakukan oleh I 
Nyoman Kondra dari Desa Tihingan (Klungkung) menuju Desa Nongan (Karangasem) dalam rangka membawa surat. Surat tersebut disembunyikan dengan memasukkan ke dalam bambu. I Nyoman Kondra dalam hal ini menyamar dengan berpura - pura mengadakan upacara adat mecaru (upacara korban) (Hasil wawancara dengan Bapak I Nyoman Nesa, 1985). Ketika pasukan I Gusti Ngurah Rai menyerbu tangsi polisi NICA di Tabanan, para pejuang menuju tempat ini dengan berjalan kaki. Pada waktu itu I Gusti Ngurah Rai beserta pasukannya kehabisan peluru. Hal ini disebabkan karena sepanjang Long March pasukan I Gusti Ngurah Rai terus terjadi kontak senjata dengan pasukan Belanda (NICA). Selanjutnya I Gusti Ngurah Rai beserta pasukannya bermarkas di Desa Marga. Satu - satunya cara untuk mendapatkan amunisi dan senjata yakni menggempur tangsi polisi NICA di kota Tabanan. Setelah perencanaan disusun dengan matang pada tanggal 18 Nopember 1946 pukul 08.00 I Gusti Ngurah Rai memerintahkan seluruh pasukannya menyerbu tangsi polisi NICA di kota Tabanan. Dalam penyerbuan ini pasukan I Gusti Ngurah Rai berjumlah 300 orang ditambah pemuda Desa Marga berjumlah 250 orang yang tergabung dalam pasukan $\mathrm{AB}$ (Anak Banteng) dan BB (Barisan Banteng). Senjata yang digunakan dalam penyerbuan ini berupa pisau belati, keris dan klewang/pedang. Kode yang digunakan dalam serbuan di malam hari karena suasana gelap menyebut kata gagak harus dijawab nila. Ini berarti teman, sedangkan jika dijawab lain berarti musuh. I Gusti Ngurah Rai dan pasukannya mulai bergerak dari Banjar Ole (Marga) menuju tangsi polisi NICA di kota Tabanan yakni dengan melalui Desa Adeng dan Desa Pengembungan yang selanjutnya tembus di sebelah selatan dari Desa Kamasan langsung menuju ke Pura Dalem Tabanan. Disini pasukan penyerbu beristirahat sebentar sambil menunggu komando lebih lanjut. Setelah mengaso sebentar pasukan penyerbu diperintahkan menyerbu tangsi polisi NICA tanpa mendapat perlawanan dari pihak musuh (NICA). Dalam serbuan ini pasukan penyerbu memperoleh : 36 pucuk karben, 2 pucuk pistol mitraliur, 2 pucuk bren, 2 pucuk senapan angin, 16 blek peluru, serta 2 buah mesin tik yang diselesaikan dalam waktu $2-3$ jam. Usaha penyerbuan tangsi polisi NICA di kota Tabanan berhasil dengan baik atas bantuan MBO Tabanan melalui Ni Made Lasti yang mengadakan komunikasi amat rapi dengan Wagimin selaku komandan polisi NICA (Ida Bagus Rama, 1984: 42). Wayan Pasek (asal dari Desa Kalianget Buleleng) pernah digunakan sebagai penghubung istimewa dari staff ke staff. Dalam situasi gawat Wayan Pasek amat diperlukan tenaganya karena paling kuat jalan kaki meskipun jarak yang di tempuh sangat jauh. Demikian halnya Made Warsa (asal dari Joanyar Buleleng) sebagai penghubung tak langsung pernah berjalan kaki ke desa Lembong. Selain itu Made Warsa juga pernah melaksanakan tugas berjalan kaki ke Desa Banjar, Desa Sidatapa, Desa Munduk, Desa Kalapaksa, dan Desa Grogak sesuai pos desa yang harus dituju (Hasil wawancara dengan Bapak I Gusti Bagus Meraku Tirtayasa, 1985). Di daerah Bangli pejuang yang termasuk penghubung istimewa adalah I Jadeng. Penghubung ini dalam melaksanakan tugas menyamar sebagai petani dimana bertugas menyelidiki perjuangan yang ada di Denpasar maupun di Singaraja. Dalam menjalankan tugas I Jadeng berjalan kaki yang jaraknya amat jauh. I Jadeng hidupnya amat sederhana tetapi dapat diandalkan sebab dapat mengetahui strategi pejuang waktu itu (Hasil wawancara dengan Bapak Ida Bagus Kaler, 1985). Di daerah Klungkung pejuang Ida Bagus Ngurah Gog pernah membawa surat dengan berjalan kaki ke Desa Sanur (Denpasar). Pada waktu ini yang dihubungi di Denpasar oleh Ida Bagus Ngurah Gog yaitu Ida Bagus Banjar dan Ida Bagus Raca (Hasil wawancara dengan Bapak I Nyoman Nesa, 1985).

-Jukung (perahu nelayan). Ida Bagus Tantra pejuang dari daerah Badung pernah menggunakan jukung ketika datang dari Jawa. Dalam perjalanan ke Bali Ida Bagus Tantra berpura - pura sebagai nelayan pencari ikan. Pada waktu ini Ida Bagus Tantra mendarat di Bali dekat lampu mercusuar di daerah Prapat Agung (Negara). Sedangkan pada waktu berangkat ke Jawa dari pulau Menjangan menggunakan perahu Bugis (Hasil wawancara dengan Bapak Ida Bagus Tantra, 1984). Pada tanggal 23 April 1947 M. Anang Aramli bersama - sama I Gusti Ngurah Mataram berangkat dari pantai Penarukan (Buleleng) 
menuju ke Jawa. Pada waktu ini M. Anang Ramli menggunakan perahu nelayan dan mendarat di pulau Kamian di sebelah timur pantai Madura (Hasil wawancara dengan Bapak M. Anang Ramli, 1985). Pada tanggal 16 Mei 1947 dari pantai Sekah (Bukit) Badung dengan menggunakan jukung (perahu nelayan) berangkat M. Setyoning, Subroto Aryo Mataram, dan I Nyoman Mantik menuju ke Banyuwangi. Agar tidak diketahui oleh Belanda dalam perjalanan di Samudra Indonesia I Nyoman Mantik menggunakan pakaian Belanda (Hasil wawancara dengan Bapak I Nyoman Mantik, 1985). Demikian halnya dengan I Gusti Ngurah Rai pada waktu berangkat ke Jawa sarana yang digunakan yaitu jukung (perahu nelayan). I Gusti Ngurah Rai berangkat dari Celukan Bawang tanggal 19 Desember 1945. Begitu pula pada waktu kembali ke Bali. Setelah \pm 3 bulan berada di Jawa atas bantuan ALRI Banyuwangi pada tanggal 3 April 1946 sekitar pukul 20.00 malam I Gusti Ngurah Rai berangkat dari Muncar (Banyuwangi) menuju Bali. Tiba - tiba pukul 03.00 pagi dari arah timur muncul 2 buah motor bot Belanda mengadakan patroli. Tanpa komentar tentara Belanda melancarkan tembakan senjata otomatisnya, karena telah mengetahui pada jukung tersebut adalah pejuang. Dalam peristiwa ini gugur Cokorda Dharma Putra dan Cokorda Rai Gambir sedangkan sisanya Cokorda Oka Sudarsana dan tukang jukungnya ditangkap oleh Belanda. Mendengar suara tembakan tersebut, I Gusti Ngurah Rai yang berada dibelakangnya sekitar $1 \mathrm{Km}$ memutuskan kembali ke Muncar (Banyuwangi). Keesokan harinya pada tanggal 4 April 1946 sekitar pukul 24.00 malam perjalanan dilanjutkan kembali ke Bali. Pada waktu ini I Gusti Ngurah Rai dengan 3 buah jukungnya mendarat di Yeh Kuning sedangkan sisanya mendarat di daerah Pulukan salah satu diantaranya yaitu Cokorda Ngurah (Hardjawiganda \& (dkk.), 1982: 107-110 bandingkan Nyoman S. Pendit, 1979 : 157) . Demikian pula halnya dengan Markadi ketika berangkat tanggal 4 April 1946. Perahu kolean/perahu Madura yang ditumpangi Markadi ditarik secara berjajar oleh sebuah kapal tunda. Apabila menggunakan jukung, maka jukung ini tidak lagi ditarik dengan kapal tunda. Namun jukung tersebut diberikan berlayar terlebih dahulu. Sedangkan untuk pengiriman pasukan pada gelombang kedua ke Bali, Markadi menggunakan perahu mayang/perahu telapak dengan cara berjajar 2 baris yang ditarik oleh 2 buah kapal tunda (Hardjawiganda \& (dkk.), 1982: 104 - 120). Begitu halnya dengan pasukan Waroka ketika dikirim dari Banyuwangi ke Bali tanggal 3 April 1946. Sarana yang digunakan untuk mengangkut pasukan ini adalah perahu mayang/perahu telapak serta perahu kolean/perahu Madura yang jumlahnya 20 buah. Ketika itu Angkatan Laut Republik Indonesia/ALRI hanya memiliki 4 buah kapal tunda antara lain: kapal tunda tajam, kapal tunda ringgit dan kapal tunda raung dipimpin oleh Moh.Ali. Sedangkan kapal tunda Baluran dipimpin oleh Saleh Suradihardja. Perahu mayang/perahu telapak dan perahu kolean/perahu Madura yang ditumpangi oleh pasukan Waroka selanjutnya ditarik oleh kapal tunda baluran, kapal tunda raung serta kapal tunda ringgit. Markas Gabungan Gerakan Soenda Ketjil (MGGSK) pada tanggal 1 Juni 1946 menggunakan jukung sebagai alat angkut. Di samping itu juga menggunakan perahu mayang/perahu telapak serta perahu kolean/perahu Madura. Kapal tersebut di atas ditarik kapal tunda ringgit dan kapal tunda baluran (Hardjawiganda \& (dkk.), 1982: 67 145).

\section{SIMPULAN}

Revolusi fisik sebagai suatu sistem tidak bisa dipisahkan dengan sub sistem yang lainnya. Demikian halnya dengan revolusi fisik yang terjadi di Bali. Transportasi sebagai salah satu sub sistem pada masa revolusi fisik di Bali yang digunakan para pejuang seperti jalan kaki, roda dua, roda empat, serta perahu. Pada masa revolusi fisik di Bali sebagian besar para pejuang menggunakan jalan kaki sebagai transportasi untuk dapat berkomunikasi antar para pejuang. Jalan kaki pada waktu ini dianggap oleh para pejuang paling aman karena dapat berubah jalur setiap saat untuk mengelabuhi musuh/Belanda sehingga keselamatannya lebih terjamin. Jalan kaki digunakan lebih banyak oleh para pejuang karena merupakan sarana yang paling efektif untuk di darat, di hutan maupun di pegunungan baik siang hari maupun malam hari tergantung 
keperluan. Meskipun demikian para pejuang juga kadang - kadang menggunakan transportasi darat seperti roda dua dan roda empat. Namun demikian transportasi roda dua dan roda empat terbatas jumlahnya tidak seperti sekarang. Sedangkan untuk di laut digunakan transportasi perahu. Transportasi roda dua, roda empat dan perahu digunakan oleh para pejuang apabila jarak yang ditempuh cukup jauh dan diketahui keadaannya aman. Transportasi di atas digunakan oleh para pejuang baik dengan cara meminjam maupun dengan cara menyewa sehingga komunikasi antar para pejuang tetap nyambung. Dengan menggunakan sarana ini ikut mendukung perjuangan di Bali sehingga para pejuang cukup lama dapat bertahan menghadapi Belanda/NICA.

\section{DAFTAR PUSTAKA}

Balai Pustaka. (2001). Kamus Besar Bahasa Indonesia. Jakarta.

Dekker, I. N. (1980). Sejarah Revolusi Nasional. Jakarta: PN Balai Pustaka.

Hardjawiganda, R., \& (dkk.). (1982). Operasi Lintas Laut Banyuwangi - Bali. Jakarta: Departemen Pertahanan Keamanan Pusat Sejarah ABRI.

Jajasan Kebaktian Proklamasi Daerah Propinsi
Bali. (1968). Sejarah Singkat Pahlawan Nasional Kolonel Anumerta I Gusti Ngurah Rai. Marga.

Kartodirdjo, S. (1970). Beberapa Masalah Teori Dan Metodologi Sejarah. Lembaran Sejarah, (6).

Kartodirdjo, S., \& (dkk.). (1977). Sejarah Nasional Indonesia VI. Jakarta: Balai Pustaka.

Nasution,A, H. (1977). Sekitar Perang Kemerdekaan Indonesia 2. Bandung: Angkasa.

Pendit, N. S. (1979). Bali Berjuang.

Pindha, I. G. N. (1964). Pertempuran Besar Tanah Aron. Denpasar: Jajasan Universitas Marhaen.

Pindha, I. G. N. (1968). Gempilan Perdjuangan Physik Di Bali, Masa - Masa Krisis XXIII. Harian Pagi Suluh Marhaen.

Pindha, I. G. N. (1972). Kirikumi Besar Besaran Terhadap Kota Denpasar. Denpasar.

Poerwadarminta, W. J. S. (1976). Kamus Umum Bahasa Indonesia. Jakarta: PN Balai Pustaka.

Wijakusuma. (1979). Kisah Perjuangan Gerilya Di Bali (8), Jadi NICA Sehari. Denpasar: Bali Post. 